\title{
Submaxillary gland pleomorphic adenoma in teen and extirpation intraoral case study and review of literature
}

\begin{abstract}
The tumors in salivary glands represents only $3 \%$ of neoplasms of the body and $1 \%$ of those are found in head and neck. They are rare in pediatric patients, less than $2 \%$ occur before age $16 y e a r s$. Pleomorphic adenoma is a benign tumor of the salivary glands formed by the combination of epithelial and mesenchymal elements. They appear between 40 and $50 y e a r s$ of age and are very rare in children, few reported cases and recurrence is common. In this paper we describe the case of a submandibular gland pleomorphic adenoma in a 13years and it is exeresis. The traditional approach for excision of the submandibular gland is performed through the transcervical route. Recently, we have described the intraoral excision and endocópic; In this case, the surgical technique used was the intraoral, where you can avoid the two most common sequelae described in transcervical approach: cervical incision scar and the risk of injury marginal mandibular branch of facial nerve. Note the indemnity of the lingual nerve and mylohyoid elements often injured by intraoral approach. Furthermore, we review to the world literature, with the aim of reinforce knowledge of these tumors and thus offer better alternatives to our patients.
\end{abstract}

Keywords: pleomorphic adenoma, submandibular gland, intraoral approach, teenager
Volume 9 Issue 2 - 2017

\author{
Jeannifer Galatrava, María Soledad \\ Fernández, Rodolfo Valera, Thaily Viloria, \\ Angel Joves, Yolenis Sanchez
}

Department of Otolaryngology Hospital Vargas of Caracas, USA

Correspondence: Jeannifer Galatrava Department of Otolaryngology Hospital Vargas of Caracas, USA, Email jeannygalatrava@gmail.com

Received: November 07, 2016 | Published: November 27, 2017

\section{Introduction}

Salivary tumors can develop in any of the salivary glands under the same histological pattern. ${ }^{1}$ Approximately $88 \%$ of salivary gland neoplasms are epithelial in origin, which belong to two main groups: the group of benign neoplasms or adenomas, which constitutes $70 \%$ of Malian salivary tumors, and malignant group which constitute $30 \%{ }^{2}$

On the other hand, we have that $80 \%$ of salivary tumors occur in the parotid, the 10 to $15 \%$ in the submandibular gland and between 5 and $10 \%$ in the sublingual and minor salivary glands. ${ }^{1,3}$ In addition, $5 \%$ of all salivary tumors have been seen in children being the most common hemangioma which as lymphangioma, develops from birth. ${ }^{1}$

In children, as in adults, the frequency is higher in women by a ratio of 2 to 1 (4). $84 \%$ develops in the parotid $10 \%$ in the small salivary glands of the upper aerodigestive tract, $5 \%$ in the submandibular gland and $0.1 \%$ in the sublingual gland. ${ }^{7,6}$ Other authors, like Fernández López et al., ${ }^{3}$ reported $85 \%$ in the parotid gland, submandibular gland in $8 \%$, and $7 \%$ in minor glands.

Histologically, pleomorphic adenomas are originated from the distal portions of the salivary ducts. ${ }^{6}$ It is called mixed tumor because it is histological polymorphism with epithelial elements, stromal and myoepithelial cells, ${ }^{1-3}$ whose action derived secretory structures myxoid and hyaline pseudocartilaginosas with calcified foci. ${ }^{1}$ Any of the components (epithelial, stromal and myoepithelial) may predominate, but all three must be present to confirm the diagnosis. The extracellular space may contain crystals. ${ }^{2}$ However, some pleomorphic adenomas show atypical features, absent in most cases: ${ }^{2,8}$ cellularity, spontaneous focal necrosis, cellular anaplasia, invasion of the capsule and hyalinization, if the latter is extensive and has lots of mitosis, additional sections should be examined to exclude the presence of a carcinoma. ${ }^{2}$

Specific immunohistochemical staining both for epithelial cells and myoepithelial, help distinguish pleomorphic adenoma. ${ }^{6}$ On the other hand, conventional radiographs and hematological studies are not a valuable contribution to the study for diagnostic purposes. ${ }^{3,9}$

Ultrasound examination is one of the most frequently used methods in the study of tumors of the major salivary glands, particularly the submandibular gland which generally provides specific parametersin defining methods: intrinsic /extrinsic injury to the parenchyma glandular, size, solid/liquid content injury, relations with the surrounding glandular parenchyma, presence of associated lymph nodes, and skin relationships.

The valuation of these parameters can be deriving key data on benign or malignant nature of the tumor. Recently, ultrasound has been proved useful as a guide for fine needle aspiration, and performs the extraction in the most suitable location. ${ }^{2}$

Certainly needle aspiration is an alternative, because with good conditions is an easy and precise technique, (some studies showed $80 \%$ agreement between diagnosis by aspiration and biopsy), and safe, though when the sample is taken there is a small cell seeding, this seems to be less than the critical mass necessary for the establishment and growth of a new injury. Importantly, to make an aspiration sampling, the injury must necessarily be larger than $1 \mathrm{~cm}$ in depth. ${ }^{9}$

Radiologically, pleomorphic adenoma is presented as a soft tissue mass well limited round or ovoid shape within the affected gland. It can have hypodense areas on CT and hyperintense on $\mathrm{T} 2$ is due to mucoid matrix areas or cystic degeneration. It has intense and homogeneous enhancement with contrast and homogeneity generally increases with time if tomographic images in later stages are compared to the contras. ${ }^{10}$

With regard to the differential diagnosis of pleomorphic adenoma, there may be mentioned, malignancies such as adenoid cystic carcinoma, ${ }^{6,2}$ which differs by the presence of a low cellularity stroma with abundant collagen, contrary to myeloid or chondroidstroma of the mixed tumor. Another feature that sets it apart is the invasive 
growth pattern and trend of cystic carcinoma invading nerves; other differential diagnoses include: polymorphous low-grade adenocarcinoma, deep adnexal tumors and mesenchymal neoplasms, ${ }^{6}$ monomorphic adenoma, mucoepidermoid tumors, which stroma is different and especially cylindromas which have not hyaline cells and the stroma is Poorer in elastic fibers. ${ }^{8}$

Otherwise, rare complications of pleomorphic adenomas include: recurrence after a few months until 40years after the excision of the tumor, when its enucleation is not complete, ${ }^{4}$ breakage of the capsule of the tumor During surgery, resection of the lesion only by enucleation or being a Multicentrictumor, ${ }^{11}$ presenting the greatest risk of recurrence in the major salivary glands. ${ }^{4}$ In second place is the malignant degeneration of $1.5 \%$ in the first five years and increases to $9.5 \%$ after more than 15 years of evolution, ${ }^{3}$ as a tumor known as expleomórfico carcinoma adenoma, or alternately, metastatic benign mixed tumors. ${ }^{6}$ The first occurs rarely in children, sometimes hematogenous spread of the tumor leads the patient to death; so in these cases, in addition to surgery, radiotherapy is advisable., ${ }^{4,6}$ The number of patients that die as a result of these neoplasms is $50 \%{ }^{4}$ Prognosis of pleomorphic adenomas is excellent with a free of $96 \%{ }^{6}$

\section{Justification}

In view of the unusual of salivary gland tumors in adolescents the intention is to describe the following case and its resolution with a no conventional surgical technique.

\section{Clinical case}

The patient is a 13aged male, who refers an increase in volume in the right submandibular region (Figure 1), progressive, occasionally accompanied by intermittent, stabbing pain which subsides spontaneously, 1year of evolution prior to consultation. His mother reported treatment with antibiotics and anti-inflammatory without improvement.

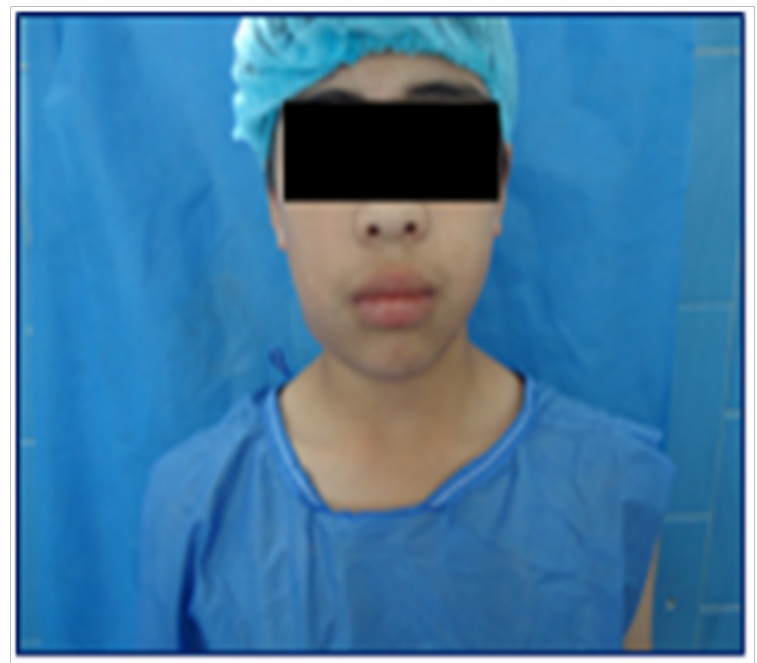

Figure I Increase in volume in the right submandibular region.

At physical examination patient calm, conscious, cooperative, located in time, place and space, with facial asymmetry, without changes in the field of ear and nose is observed. Intraoral examination: buccal mucosa moist, pink, permanent dentition, without the presence of septic foci. Lips, cheek, palate, tongue, floor of mouth and or pharynx with no apparent alterations observed. In the cervical assessment can be seen upon inspection, bulking right submandibular region with coloration similar to the rest of the integuments. Palpation: hard consistency of $3 \times 3 \mathrm{~cm}$ dimensions, painless, with limited edges, low mobile, which impresses adhered to deep planes, with bilateral cervical lymphadenopathy associated. Mobile and not painful of $0.5 \mathrm{~mm}$ in diameter.

Image studios (cervical sonogram and CT scan) reported: Increased volume of the submandibular gland on the right side with impaired surrounding fat, with displacement of the cervical fascia.

Cervical bilateral lymphadenopathy predominantly located below sternocleidomastoid and submandibular location. There is a small plastron of about $2 \mathrm{~cm}$ in the cervical chains on the right side behind and below the ipsilateral sternocleidomastoid (Figures 2). Subsequently, ultrasound soft tissue neck region, described, three images of nodular, adjacent hypoechoic aspect of regular shape, the larger diameter $2,7 \mathrm{~cm}$ and two of 1.3 and $1.7 \mathrm{~cm}$. Left submaxillary region: two similar nodes of that measured 1.5 and $1.2 \mathrm{~cm}$ in diameter (Figure 3) were observed.

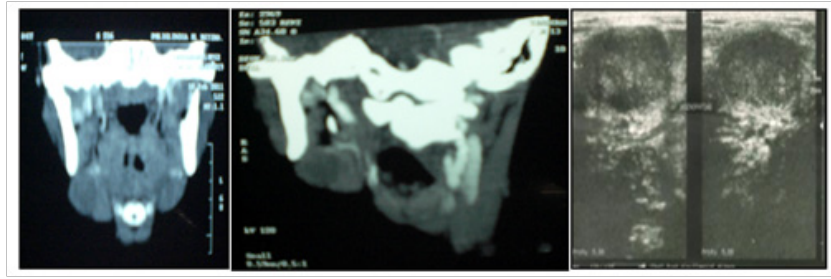

Figure 2 There is a small plastron of about $2 \mathrm{~cm}$ in the cervical chains on the right side behind and below the ipsilateral sternocleidomastoid.

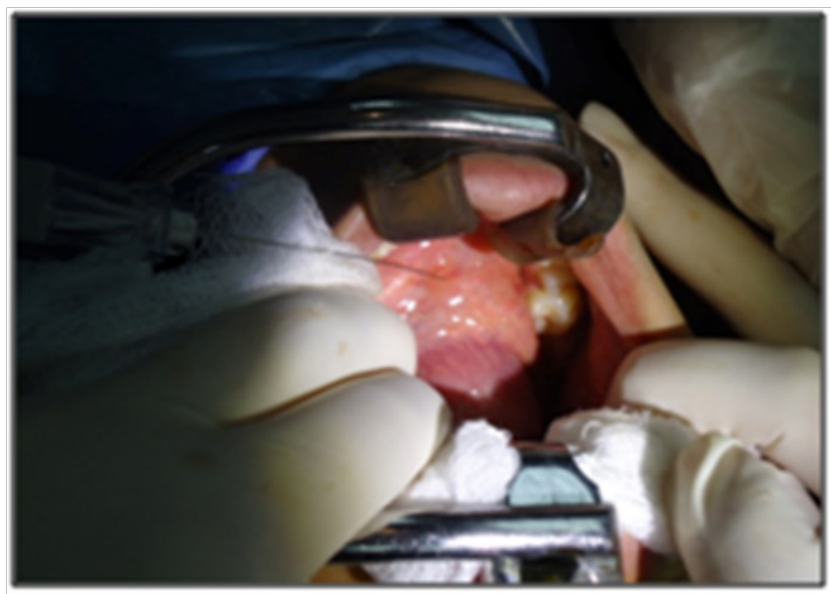

Figure 3 Preoperative studies were normal. Puncture is performed with fine needle whose cytology report concludes.

Preoperative studies were normal. Puncture is performed with fine needle whose cytology report concludes: Pleomorphic Adenoma. Later he prepares for surgery removal of submandibular gland with tumor intraorally (Figures 4) under general anesthesia with nasotracheal intubation.

Sample obtained is represented by tumor of $3 \times 2 \mathrm{~cm}$, pearly white, bilobed, well-defined (Figure $5 \& 6$ ), whose biopsy reports: Pleomorphic Adenoma. In its evolution during the immediate postoperative period there was moderate presence of pain and edema in the area; then the patient was observed, in good general condition and without observing immediate or late postoperative complications during follow-up, which consisted of a monthly check for 4months (Figures 7). 


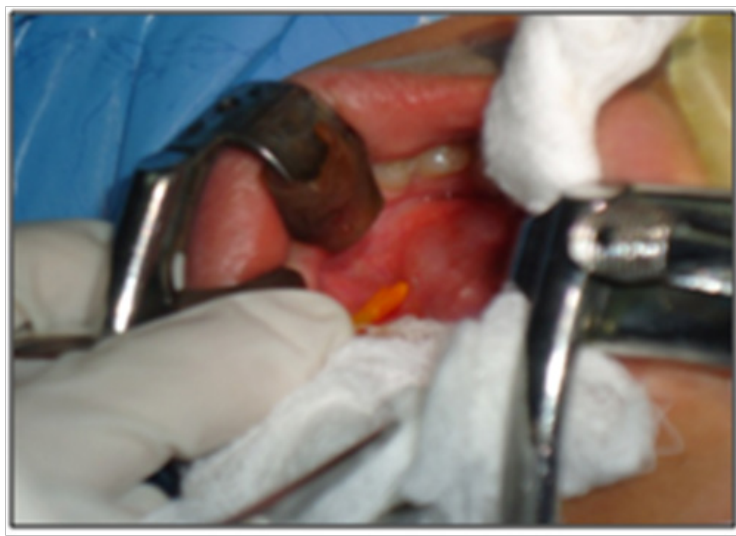

Figure 4 Lidocaine with epinephrine $(1: 100,000)$ is injected into the mucosa to achieve hemostasis.

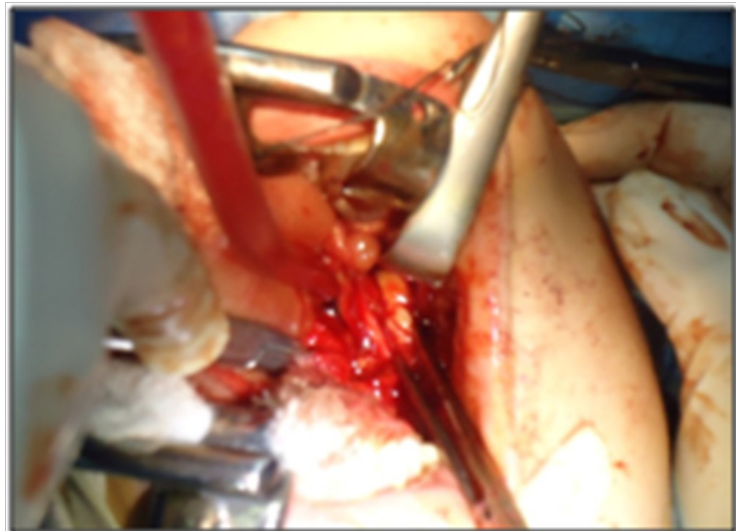

Figure $5 \mathrm{~A}$ probe is inserted into Wharton ductmeatus.

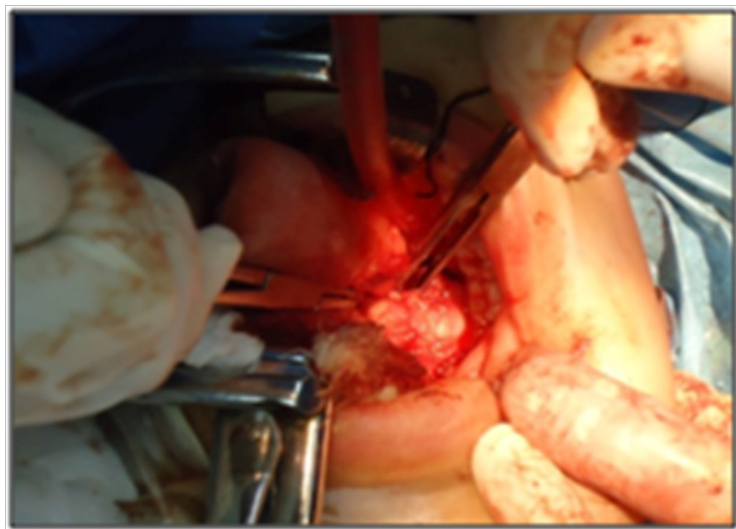

Figure 6 A careful dissection along the path of through Wharton duct shows its intimate relationship with the lingual nerve. The separation of the tongue and floor of the mouth including the lingual nerve, displays the mylohyoid muscle. The previous separation of the posterior margin of mylohyoid allows to visualizes the surface portion of the submandibular gland.

\section{Discussion}

Tumors that occur in the salivary glands represent only $3 \%$ of neoplasms of the body and $1 \%$ of those found in head and neck. ${ }^{1}$ Of these, only $2 \%$ occur before age $16 y$ ears. Most of the revision articles represent few case series. ${ }^{7}$ Notably, the pleomorphic adenoma is a mixed tumor ${ }^{1,3,6}$ causing 80 to $90 \%$ of benign tumors of the salivary glands, ${ }^{1,3,8,9}$ in patients between 30 and 60years of age, being more common in females. ${ }^{6,8,9,11}$ Less than $10 \%$ was observed in children, ${ }^{4.9}$ there are few reported cases and relapse is common. However, the patient presented here is a 13year old male, which contrasts with the statistics published in the literature (Figure 8).

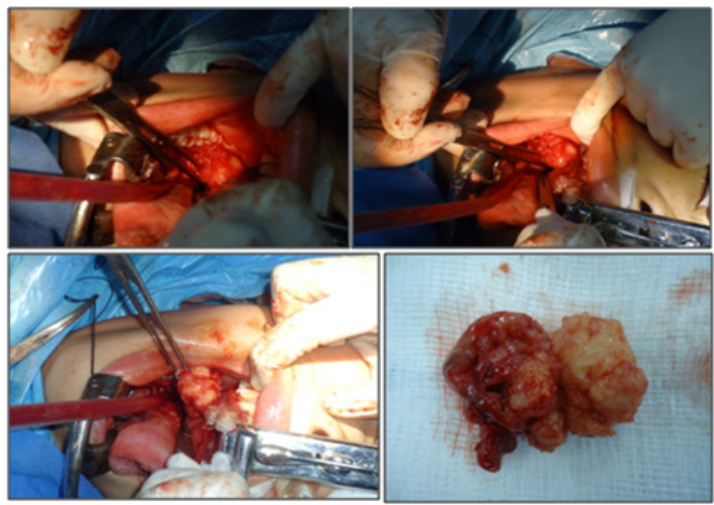

Figure 7 Blunt dissection is used to release the submandibular gland surrounding structures.

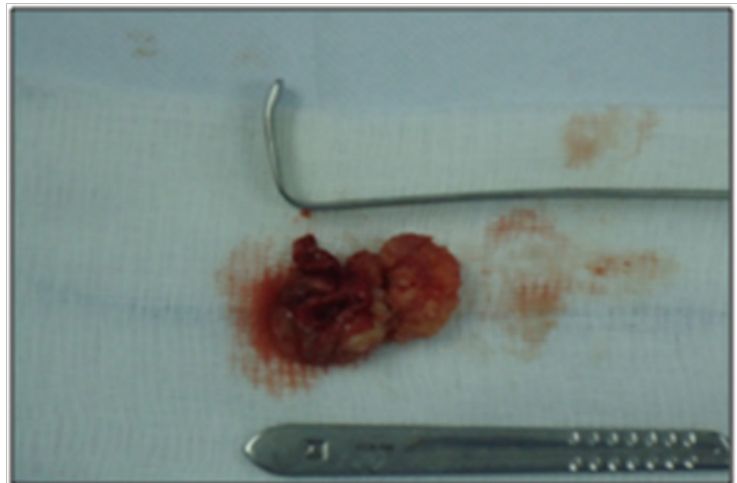

Figure 8 Sample obtained is represented by tumor of $3 \times 2 \mathrm{~cm}$, pearly white, bilobed.

Certainly $84 \%$ of these tumors develop in the parotid gland, while only $5 \%$ in the submandibular gland, which makes more significant the case, reported here, more because of settlement of tumor in the submandibular gland.

Contrary to the above, the signs and symptoms that suggest the presence of a pleomorphic adenoma are unspecific, ${ }^{4}$ patient refers usually a mass, edema or small nodule, isolated in the submaxillary gland progressively increasing size, showing growth and sometimes intermittent mild pain associated. ${ }^{3,4,6}$ For its polymorphism is pathognomonic the existence of areas of different consistency: elastic, renitente or pseudocystic. Being very hard those with a major cartilage component (Nélaton sign). ${ }^{1}$ Clinical reported by the patient presented here, in this case the consistency at tumor palpation was hard (Figure 9).

In reference to the treatment, complete surgical excision of the tumor with wide excision, together with the free margins disease is recommended. ${ }^{6,8,11}$ The traditional approach for cleavage of the submandibular gland, is performed through the transcervical approach, although is also intraoral and endoscopic excision.

An alternative surgical approach to the submandibular gland is the intraoral, which was used in this patient because through this procedure can avoid the two most frequent adverse consequences of transcervical approach, first and considering that it is a teenager, 
scar cervical incision, and secondly, the risk of injury to the marginal mandibular branch of the facial nerve, as the branches of the facial nerve are not exposed in this procedure, so not identified during this dissection.

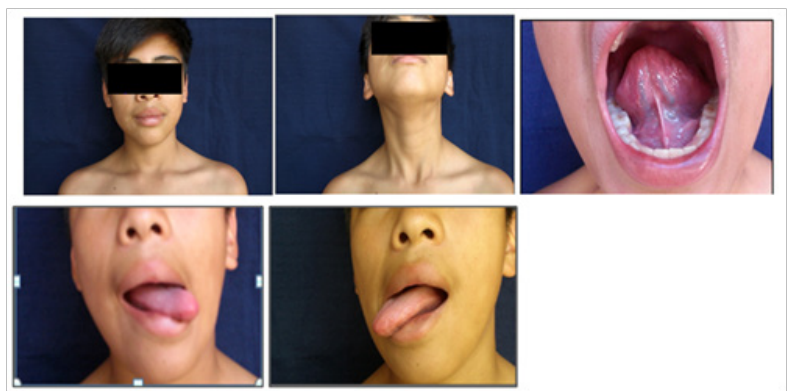

Figure 9 the patient was observed, in good general condition and without observing immediate or late postoperative complications during follow-up.

The intra-oral route, requires nasotracheal intubation, after which lidocaine with epinephrine $(1: 100,000)$ is injected into the mucosa to achieve hemostasis. After inserting a probe into the Wharton's duct meatus, an intraoral incision is made through the mucosa of the floor of the mouth, from the meatus behind the lingual side of the retromolar region. A careful dissection along the path through Wharton is duct shows its intimate relationship with the lingual nerve.

The separation of the tongue and floor of the mouth including the lingual nerve, displays the mylohyoid muscle.

The previous separation of the posterior margin of mylohyoid allows to visualize the surface portion of the submandibular gland. Blunt dissection is used to release the submandibular gland of surrounding structures. Applying transcervical submandibular gland pressure on the floor of the mouth helps viewing, and gland is removed carefully and hemostasis is performed. A drain can be inserted through the incision, whereafter the mucosa is reapproximated with an absorbable suture, thus concluding the surgical procedure.

However intraoral approach risks stem from the significant separation of the floor of the mouth, including the lingual nerve and the mylohyoid muscle, which is necessary to achieve adequate exposure of the gland. ${ }^{12}$ Also can occur, hypoglossal nerve paralysis, postoperative bleeding and postoperative infection. Lingual nerve paralysis is manifested by gustatory and sensory anesthesia of the corresponding mobile hemitongue and sometimes painful paresthesia.

As a result of these changes patients can present burns and bites of tongue. Paralysis of the hypoglossal nerve leads to a motor paralysis of the ipsilateral hemitongue, deviations toward the paralyzed side, with twitches and atrophy. ${ }^{5}$

\section{Conclusion}

Pleomorphic adenoma, despite being a condition found between the third and sixth decade of life, is a condition that must be present below 16years at the time of a chronic process of the salivary glands. Finally it is worth noting as an option for the removal of the submandibular gland, intraoral pathway which seems to achieve its goals of eliminating the need for a transcervical approach and minimize the risks of damage of the branches of the facial nerve, being the marginal mandibular nerve which injured more often in the traditional transcervical approach, with injury rates include 1 to $7 \% .^{10}$ So, the patient is solved with better a esthetic alternative. ${ }^{10}$ It was the technique used in this case.

\section{Acknowledgments}

None.

\section{Conflicts of interest}

Author declares there are no conflicts of interest.

\section{Funding}

None.

\section{References}

1. Fazzini, Romeo. Tumores de Glandul Salivales. Facultad de Medicina de Buenos Aires. Unidad Académica Hospital Municipal de San Isidro, Argentina. 2000

2. Ceceñas FLÁ, Rivera LOS, Galdamez TA, et al. Tumores Epiteliales de la Población Pediátrica del Hospital Universitario In: José \& E González (Eds.), Estudio retrospectivo de 11 Años. Patol Rev Latinoam. 2010;48(4):234-235.

3. Pineda K, Luna YA. Anatomía Patológica. Tumores de Glándulas Salivales. In: En Suárez C, et al. (Eds.), Tratado de Otorrinolaringología y Cirugía de Cabeza y Cuello. 2009. p.3630-3631.

4. Pérez S, Cols Y. Adenoma Pleomorfo de Glándula Submaxilar izquierda; Reporte de un Caso Clínico. Asociación Mexicana de Cirugía Bucal y Maxilofacial, Colegio Mexicano de Cirugía Bucal y Maxilofacial, AC, México. 2011;7(1):5-9.

5. Shin F. Enfermedades Benignas de las Glándulas Salivales. In:En Lalwani A \& Diagnóstico Y (Eds.), Tratamiento en Otorrinolaringología, Cirugía de Cabeza y Cuello, México. 2005. p.296-297.

6. Fontanel J, Poitout, Klossek FY. Tumores de las Glándulas Salivales. Encyclopedie Médico-Chirurgicale (1st edn), Scientifiques ET Médicales Elsevier SAS, París, France. 2000.

7. Pedemonte C, Basili A, Montero S. Adenoma Pleomorfo de Glándulas Salivales Menores. Revista Dental de Chile, USA. 2003;94(3):18-21.

8. Escajadillo J. Oídos, Narís, Garganta y Cirugía de Cabeza y Cuello. Manual Moderno, México. 2002. p.781.

9. Ledezma C, Garcés M, Gómez L, et al. Adenoma Pleomorfo. Revista de la Asociación Dental Mexicana, Mexico. 2002;2:58-61.

10. Dehesdin D, Vinel YV. Cirugía de la Glándula Submáxilar, Cirugía de la Glándula Sublingual. Encyclopedie Médico- Chirurgicale. (1st edn) Scientifiques ET Médicales Elsevier SAS, París, France. 2000.

11. Fischbein N, Kenneth Y, C Radiología, et al. Diagnóstico y Tratamiento en Otorrinolaringología, Cirugía de Cabeza y Cuello, México. 2012. p.68-69.

12. Fraioli R, Grandis J Extirpación de la Glándula Submandibular. In: Mayers E (Ed.), Otorrinolaringología Quirúrgica, Cirugía de Cabeza y Cuello, España. p.505-509. 